2013

\title{
Issuing New Shares and Preemptive Rights: A Comparative Analysis
}

Marco Ventoruzzo

Penn State Law

Follow this and additional works at: http://elibrary.law.psu.edu/fac_works

Part of the Business Organizations Law Commons, and the Securities Law Commons

\section{Recommended Citation}

Marco Ventoruzzo, Issuing New Shares and Preemptive Rights: A Comparative Analysis, 12 Rich. J. Global L. \& Bus. 517 (2013).

This Article is brought to you for free and open access by the Faculty Works at Penn State Law eLibrary. It has been accepted for inclusion in Journal Articles by an authorized administrator of Penn State Law eLibrary. For more information, please contact ram6023@psu.edu. 


\section{Marco Ventoruzzo*}

\section{ISSUING NEW SHARES AND PREEMPTIVE RIGHTS: A COMPARATIVE ANALYSIS}

\section{Introduction}

The question of whether the corporate laws of Europe and America are converging is still largely unanswered. ${ }^{1}$ One fundamental area in which the two systems diverge concerns how they regulate the issuing of new shares, in particular preemptive rights-a problem rarely addressed by comparative corporate law scholars. ${ }^{2}$ This essay fills that gap by examining the major comparative differences between the approaches followed on the two sides of the Atlantic and offers some possible explanations for this divergence.

The issuing of new shares by a corporation is often a recipe for litigation. In fact, when new shares are issued and not offered to existing shareholders, shareholders may suffer two types of damages. On the one hand, shareholders' voting power within the corporation is diluted. On the other hand, the value of their investment can be reduced if the selling price is lower than the actual value of the shares.

Consider the following scenario. Corporation XYZ, worth four million dollars, has 1,000 shares outstanding. Shareholder A owns $25 \%$ of the shares (250 shares). A controls one-fourth of the voting power, and the value of her investment is one million dollars. If the corporation issues 1,000 new shares and sells them to a third party, A's voting power is reduced to $12.5 \%$ (250 shares over 2,000 outstanding). Depending on the price at which the new shares are offered, the value of A's investment could also be jeopardized. If XYZ sells the new shares at $\$ 4,000$ each (the value before the new issue), no damage is caused. In fact, A will still own $12.5 \%$ of a corporation worth eight million dollars, which equals one million dollars. If, however, XYZ

* Professor of Law, Bocconi University, Milan, Italy, and Penn State Dickinson School of Law; State College, PA, USA; External Scientific Member, Max Planck Institute Luxembourg. I wish to thank Catherine Rogers for her precious suggestions. Excellent research assistance was provided by Elizabeth Robinson.

1 See Corporate Governance Regimes: Convergence and Diversitry (Joseph A. McCahery et al. eds., 1st ed. 2002); Ronald J. Gilson, Globalizing Corporate Governance: Convergence of Form or Function, 49 AM. J. CoMP. L. 329 (2001); Douglas M. Branson, The Very Uncertain Prospect of "Global" Convergence in Corporate Governance, 34 CoRNell INT'L L. J. 321 (2001).

${ }^{2}$ Reiner R. Kraakman et al., The Anatomy of Corporate Law: a Comparative and FunCtional ApProach 192 (Oxford University Press, 2nd ed. 2009) (giving a brief comparative overview of the regulation of share issuance). 
sells the shares at a "discount," the value of A's investment will be proportionally reduced. If, for example, the new 1,000 shares are sold for $\$ 3,000$ each, the value of A's stake in the corporation will decrease to $\$ 875,000(12.5 \% * \$ 7,000,000)$.

Of course the law could dramatically curb this risk by providing that all existing shareholders always have a mandatory preemptive right to buy newly issued shares. Similar protections, however, would be detrimental to the corporation. It is essential that directors retain a certain degree of flexibility in designing the financial structure of the corporation. Granting preemptive rights to shareholders is time-consuming because the shares must be first offered to existing stockholders and might hinder the ability of the corporation to quickly obtain fresh financial resources when market conditions are favorable. The law must therefore strike a delicate balance between the protection of existing shareholders, on the one hand, and the ability of the corporation to pursue its optimal financial structure, on the other.

There are three basic sets of rules that contribute to strike such a balance: rules concerning the allocation of powers between directors and shareholders to decide on the issuing of new shares, preemptive rights in case new shares are sold, and fiduciary duties of directors engaging in the sale of new shares. The purpose of this essay is to consider how different legal systems strike this balance in regulating the issuance of new shares, focusing in particular on preemptive rights. The comparison is not only important for the relevance of the problem, but also because it illuminates some of the fundamental differences in the corporate governance philosophies underlying different legal systems.

This essay compares the systems in the U.S. and continental European jurisdictions with particular reference to Italy. Focusing on these systems is particularly apt because the two models follow nearly opposite approaches. In the U.S., directors enjoy broad powers in the issuing of new shares, and there is greater freedom of contract in regulating preemptive rights in the corporate charter. Under this system, shareholders are mainly protected through directors' fiduciary duties. In Europe, shareholders are protected through statutory rules that mandate preemptive rights. Shareholders have the power to waive preemptive rights, but only in limited circumstances.

One might argue that European systems still follow the approach adopted in the U.S. until roughly the 1960 s, and a possible explanation is that Europe did not experience the same separation between ownership and control that occurred in the U.S. The comparison will allow exploration of a more general difference between shareholder protection in the U.S. and in the civil law systems of continental Europe, namely, the fact that the former jurisdiction relies more on expost litigation, and the latter on ex-ante mandatory rules. 
Part I analyzes the American regulation of the issuing of new shares. Part II turns to its European counterpart, with a focus on the Italian system. Part III concludes by pointing out the differences in approaches to this crucial legal issue.

\section{PART I: U.S. LAW}

\section{Competence to Issue New Shares}

In the U.S., the power to issue new shares is primarily entrusted to the board of directors. Directors enjoy a great degree of freedom in issuing new shares; however one important limitation is that they can only issue the number of shares authorized by the articles of incorporation. ${ }^{3}$ Generally, corporations have outstanding shares, which are shares already sold to shareholders that form the capital of the corporation; but the articles of incorporation provide for additional authorized shares that directors can issue and sell. ${ }^{4}$ For example, a corporation can have 100 outstanding shares held by two shareholders, but the articles of incorporation can authorize the issuing of an additional 200 shares. If directors want to issue more than the additional 200 shares, they need to obtain shareholders' approval to increase the number of the authorized shares.

This rule gives shareholders some control over the financial structure of the corporation. Sales of shares that might dilute shareholders' ownership of the corporation above the threshold set by the authorized shares must be voted by shareholders as an amendment to the articles of incorporation. ${ }^{5}$ The practice, however, is to provide for a number of authorized shares significantly larger than the number of outstanding shares, so that if new financial resources are needed, directors can easily issue new shares. In contrast to European law, issuing new shares in the U.S. is substantially and practically in the hands of directors. ${ }^{6}$ In addition, minority shareholders in corporations with a controlling shareholder derive little protection from this rule because majority shareholders can consent to increase the number of authorized shares.

\footnotetext{
3 See Andreas Cahn \& David C. Donald, Comparative Company Law 205 (Cambridge University Press, 2010) (stating that, in Delaware "[w]ithin the limits of the authorized stock, the board of directors is free to issue stock on its own authority until all the authorized stock has been issued. Delaware law thus places considerably more power in the hands of the board than either Germany or the United Kingdom.").

${ }^{4}$ See generally Model Bus. Corp. Act $\$ \S 6.01,6.02$ (2002); Del. Code AnN. tit. 8, $\S 161(2010)$.

5 See Franklin A. Gevurtz, Corporation Law 135 (West, 2000); see also Mira Ganor, The Power to Issue Stock, 46 WaKe Forest L. REv. 701, 709 (2011).

${ }^{6}$ See generally Del. Code ANN. tit. 8, §§ 141, 161.
} 
One exception to this allocation of powers is established by M.B.C.A. § 6.21(f), which requires shareholders' approval if (i) the shares are issued for consideration other than cash, and (ii) the voting power of shares that are issued comprises more than 20 percent of the voting power of the outstanding shares. ${ }^{7}$ Also in listed corporations, shareholders' approval is necessary when the issuing of new shares might determine a shift in control. Rules enacted by the NYSE, the NASD, and the American Stock Exchange require a vote at the shareholders' meeting when a listed corporation issues an amount of new common shares exceeding $20 \%$ of the outstanding ones, if the issuance is not made through a public offer for cash. ${ }^{8}$

\section{Preemptive Rights}

Another way to protect shareholders in the event new shares are issued is to grant them a preemptive right to purchase these shares. ${ }^{9}$ In this case, shareholders who want to avoid the dilution of their participation can acquire pro-rata the new shares paying the required consideration. ${ }^{10}$ of course, this protection is effective only to the extent that shareholders have the financial means and the willingness to buy the new shares but if they do, no dilution will occur.

The traditional approach in the U.S. was that shareholders enjoyed preemptive rights. ${ }^{11}$ This was the rule followed at common law. Probably the first case to enunciate preemptive rights was Gray $v$. Portland Bank, a Massachusetts case decided in 1807.12 The first general corporation statutes followed this judicial doctrine and granted preemptive rights to shareholders. Massachusetts is an interesting example, as chapter 179 of the Acts of 1870 provided that whenever a corporation increased its capital stock, it was required to give notice to each shareholder, and the shareholders were able to buy the new shares pro-rata at their par value. ${ }^{13}$ Interestingly, and in contrast to what is provided in other legal systems, shareholders were only entitled to a pro-rata preemptive right: if some shares remained unsold, the directors could sell them on the market. However, any premium (the difference between the par value and the selling price) had to be

${ }^{7}$ Stephen M. Bainbridge, Corporate Law 39 (Foundation Press, 2nd ed. 2009).

8 KraAkman, supra note 2, at 194.

${ }^{9}$ See Ganor, supra note 5, at 706.

${ }^{10} I d$.

11 See Gevur'z, supra note 5, at 136 n. 61 (citing Stokes v. Cont'l Trust Co., 78 N.E. 1090 (N.Y. 1906), which provides an illustration of the traditional approach in the U.S.).

${ }^{12}$ See Andrew L. Nichols, Shareholder Preemptive Rights, 39 Bos. BAR J. 4, 4 (1995) (citing Gray v. Portland Bank, 3 Mass. 363 (1807)).

${ }^{13}$ See id. 
paid to the shareholders that had not exercised their preemptive right in proportion to their shares. ${ }^{14}$

Preemptive rights might, however, interfere with the ability of the corporation to raise new funds, if nothing else because the need to give some time to existing shareholders to exercise their right slows down the sale of the new shares. Some early amendments to general corporation statutes simply provided that shareholders could determine the terms and manners of the disposition of newly issued shares, meaning that they could limit or exclude preemptive rights. This was the case, for example, with the 1903 Acts of Massachusetts. ${ }^{15}$

More modern corporate statutes abandon this approach and generally deny preemptive rights unless the governing documents of the corporation opt for them. The default rule is that shareholders do not have a preemptive right in case of issuance of new shares, unless the articles of incorporation (or sometimes, the bylaws) expressly provide so. ${ }^{16}$ In Massachusetts this rule was adopted in 1964, under chapter $156 \mathrm{~B}$, section 20 of the general corporation statute. ${ }^{17}$ The M.B.C.A. and Delaware law also provide for similar rules. ${ }^{18}$

Notably, there are some differences in how preemptive rights are structured. Some statutes allow shareholders to opt-in to preemptive rights, both in the charter and in the bylaws of the corporation. The effect is obviously different, because if the rule is in the charter, shareholders' approval is necessary to amend it, while if it is in the bylaws, directors could be able to amend it without shareholders' consent. It follows that shareholders' rights are more protected if the preemptive rights are set forth in the articles of incorporation. ${ }^{19}$

Alternatively, a different approach followed by a minority of corporate statutes provides an opt-out mechanism for some corporations. Under this regime, shareholders enjoy preemptive rights as a default rule, but the articles of incorporation can waive them. ${ }^{20}$

\footnotetext{
14 See id.

${ }^{15}$ See E. Merrick Dodd, Jr., Statutory Developments in Business Corporation Law, 1886-1936, 50 HARv. L. REv. 27, 37 (1936) (outlining the provisions of Mass. Acts \& Resolves 1903, c. 437).

16 See Gevurtz, supra note 5, at 136 n. 63.

17 See Mass. Gen. Laws ch. 156B $\$ 20$ (1964).

18 Model Bus. Corp. Act $\S 6.30$ (2002); Del. Code AnN. tit. 8, $§ 102(b)(3)$ (2012).

${ }^{19}$ More precisely, in some jurisdictions shareholders can prevent the risk that directors will amend a bylaws rule introduced by them by explicitly providing that directors do not have this power. See Model Bus. CoRp. ACT $\S 10.20$ (b). There are more doubts that this is possible under Delaware law. See BAINBRIDGE, supra note 7 , at 16 .

${ }^{20}$ Gevurtz, supra note 5, at 136 n. 6 (citing N.Y. BUS. CoRP. $\$ 622$ (providing a similar rule for corporations formed before 1997).
} 
Whether shareholders can individually negotiate for preemptive rights in a separate contract with the corporation presents an interesting interpretive question. If this is not possible, the only way to grant preemptive rights would be to include them in the governing documents of the corporation. If individually negotiated rights are permissible, however, it would be possible that only some shareholders would enjoy preemptive rights. If such agreements are not permitted, all shareholders in a similar situation would be able to exercise preemptive rights. The language of most statutes raises this ambiguity; for example, section 102(b)(3) of the Delaware General Corporation Law provides, in relevant part, that: "No stockholder shall have any preemptive right to subscribe to an additional issue of stock or to any security convertible into such stock unless, and except to the extent that, such right is expressly granted to him in the certificate of incorporation." 21

There are two possible readings of such a provision. On the one hand, it can be interpreted as simply repealing the previous rule according to which shareholders had, as a general matter, preemptive rights, and stating how general preemptive rights can be established. If this interpretation is adopted, the statute does not prohibit shareholders from entering into a separate contract with the corporation to enjoy preemptive rights. The statutory provision could, however, also be given a broader meaning. Under this reading, the only way to grant preemptive rights is to include them in the charter and, therefore, make them available to all shareholders. The first interpretation is preferable, and it seems supported by the limited authority existing on the point. ${ }^{22}$

Even when the articles of incorporation provide for preemptive rights, several delicate problems can arise, especially when the corporate contract does not regulate all the situations that can arise in the life of a corporation. The most important of these questions are discussed below.

\section{Interpretation Questions on the Applicability of Preemptive Rights}

The first issue concerns the possibility for existing shareholders to exercise their preemptive rights only pro-rata. Imagine, for example, that a corporation has issued 200 shares, and that its two shareholders own 100 shares each. If the corporation issues 100 new shares and only one shareholder exercises her pre-emptive right, she would be allowed to buy 50 shares in order to maintain her $50 \%$ stake

${ }^{21}$ Del. Code Ann. tit. 8, 102(b)(3).

${ }^{22}$ See Nichols supra note 12, at 26 (citing Garza v. T.V. Answer, Inc., Civ. A. No. 12784, 1993 WL 77186 (Del. Ch., March 15, 1993)). 
in the corporation. In this scenario, can she also exercise her preemptive right on the remaining 50 shares that the other shareholder decided not to buy, or can these shares be freely sold to third parties by the directors? The existing shareholders might have an interest to prevent new investors from becoming shareholders, something that, especially in a close corporation, can be highly desirable. The answer depends on how the preemptive right clause is written in the charter, and the scope of the preemptive right is something that the drafters of the articles of incorporation should take into careful account. However, it is worth noting that even old corporate law statutes that provided for preemptive rights limited these rights to a pro-rata percentage of the newly issued shares.

Another important problem can occur when the corporation wants to issue new shares for a consideration in kind, such as property or services. If the corporation is issuing new shares for cash, the exercise of a preemptive right set forth in the articles of incorporation is simple: since cash is fungible, shareholders will pay the price set for the shares and acquire the new securities issued. However, when the corporation wants to obtain property, such as the assets of another corporation, real estate from a third party, or services from a specific individual or business, shareholders simply cannot offer to the corporation the same consideration that it is seeking to obtain. In this case, therefore, courts tend not to apply preemptive rights, unless the articles of incorporation explicitly state so. ${ }^{23}$ This solution is adopted also by the M.B.C.A. $\$ 6.30(\mathrm{~b})(3)(\mathrm{iv}){ }^{24}$

The issue arose in a 1930 Maryland case, Thom v. Baltimore Trust Co. ${ }^{25}$ The Baltimore Trust intended to issue new shares in exchange for the shares of National Union Bank of Maryland. Two-thirds of the shareholders of the former company approved the plan, which required Baltimore Trust to issue 15,000 shares at a price of $\$ 112$ per share, for the purpose of acquiring 10,000 shares of National Union Bank at a valuation of $\$ 168$ per share. ${ }^{26}$ The increase of the capital of Baltimore Trust was approved as a charter amendment, but a contemporaneous amendment introduced a preemptive right in case new shares were issued, also providing, however, that the directors could issue stock without preferential subscription rights in order to accomplish a merger or acquisition. ${ }^{27}$ The Court of Appeals of Maryland reasoned that the charter provision complied with the then-established

\footnotetext{
${ }^{23}$ See generally Thom v. Baltimore Trust Co., 148 A. 234 (Md. 1930).

24 Model Bus. Corp. ACt $\$$ 6.30(b)(3)(iv).

25 Thom, 148 A. at 234.

${ }^{26} \mathrm{Id}$.

${ }^{27}$ Id. at 235 .
} 
doctrine of preemptive right, and it legitimately excluded preemptive rights when new shares were issued for property. ${ }^{28}$

A somewhat similar situation might occur when a corporation wants to issue new shares as part of a compensation scheme for its employees and officers. Do preemptive rights also apply to these transactions? In this case, the corporation has an interest in ensuring that the new shares are attributed to the employees. The M.B.C.A. provides that, in the absence of an explicit provision to the contrary in the charter, no preemptive rights apply when new shares are issued as compensation to directors, officers, and employees of the corporation. ${ }^{29}$

Another important exception to the preemptive rights rule concerns mergers. Similar to what happens in case of a contribution in kind, in a merger the assets of the merged corporation are transferred to the acquiring corporation, which issues new shares that will be given to the shareholders of the merged corporation according to an exchange ratio. ${ }^{30}$ If the shareholders of the buyer could exercise their preemptive rights, a stock-for-stock merger would not be possible. Unless expressly provided in the governing documents of the corporation, courts tend to exclude preemptive rights in case of merger. Also in this context, the interest of the corporation to accomplish the merger is considered superior to the shareholders' interest in maintaining their stake in the corporation. In addition, shareholders are protected by appraisal rights for dissenting shareholders ${ }^{31}$ and, as will be discussed below, by fiduciary duties of directors. Directors engaging in an unfair merger, in which the exchange ratio does not accurately reflect the value of the two merging corporations, can be liable for breach of their duty of care or of loyalty. ${ }^{32}$

To sum up, there are situations in which, even if a general preemptive right is included in the governing documents of the corporation, courts could deny the right after weighing the interests of the corporation and of the shareholders. Three of the most important cases have been mentioned above: when the corporation is issuing new shares for property or services, as compensation to employees, and in the case of a merger. In all of these situations, granting the exercise of preemptive rights can adversely affect the corporation, which might not be able to pursue its goals. Following the same rationale as the

\footnotetext{
${ }^{28} I d$. at 236.

${ }^{29}$ Model Bus. Corp. ACT $\S 6.30(\mathrm{~b})(3)$.

${ }^{30}$ See generally Frederic A. Bittner, Capital Stock-Corporations-Members and Stockholders-A Minority Shareholder Has a Primary Cause of Action for Denial of Preemptive Rights in a Corporate Merger, 42 TEx. L. REv. 908 (1964).

${ }^{31}$ One of the best analyses of the role and regulation of appraisal rights in the United States can be found in Robert B. Thompson, Exit, Liquidity, and Majority Rule: Appraisal's Role in Corporate Law, 84 Geo. L.J. 1, 15 (1995).

${ }^{32}$ See GevurTz, supra note 5, at 654.
} 
basis of the preemptive rights doctrine, courts will generally limit the application of preemptive rights in these circumstances, unless the charter or bylaws of the corporation expressly indicates that these rights apply. ${ }^{33}$

So far we have considered situations in which the corporation had only issued one class of shares. What happens, however, when there are different classes of outstanding shares? If, for example, the corporation has common and preferred shares outstanding, and issues new common stock, do owners of preferred shares have a preemptive right on the newly issued shares? The M.B.C.A. generally excludes preemptive rights among different classes of shares. ${ }^{34}$ This position is coherent with case law on the issue. ${ }^{35}$ Some authors have suggested a more nuanced approach, arguing that preemptive rights should be granted when the issuing of new shares would have an impact on the economic or voting rights of a class. ${ }^{36}$ This approach is probably preferable, but it is difficult to apply because in many instances it is not clear when the issuing of new shares affects, at least indirectly, other classes of shares.

\section{Sale of Treasury Shares and Preemptive Rights}

A situation similar to the issuing of new shares occurs when the corporation sells treasury shares. Treasury shares are shares that the corporation issued to shareholders but later repurchased. ${ }^{37}$ The buy back of own shares raises an issue of equal treatment of shareholders; if the corporation selectively purchases shares only from some shareholders, the ones left out might complain that controlling shareholders or directors abused their power to favor certain shareholders. $^{38}$ When the corporation resells the shares, from an economic standpoint, the situation is similar to the selling of newly issued shares.

\footnotetext{
${ }^{33}$ See id. at 136,654 .

${ }^{34}$ Model. Bus. Corp. ACT $\S 6.30(\mathrm{~b})(4)$, (5).

${ }^{35}$ See Gevurtz supra note 5, at 137. But see Thomas Branch \& Co. v. Riverside \& Dan River Cotton Mills, Inc., 123 S.E. 542 (Va. 1924) (recognizing a preemptive right of preferred shareholders to subscribe newly issued common stock.

${ }^{36}$ Gevurtz supra note 5, at 137.

${ }^{37} \mathrm{Id}$.

38 In the famous case of Donahue v. Rodd Electrotype Company of New England, Inc., 328 N.E.2d 505 (Mass. 1975), the Supreme Judicial Court of Massachusetts held that stockholders in a closely held corporation owe one another the same fiduciary duties as partners in a partnership, and that therefore, if the corporation buys back shares from a controlling shareholder, then the controlling shareholder should grant an equal opportunity to minority shareholders to sell their shares at the same price.
} 
Once again, the position of existing shareholders might be jeopardized because their voting powers and economic rights might be diluted by the sale of shares. Some corporate statutes, in fact, have extended the common law preemptive rights rule to include sales of treasury shares. ${ }^{39}$ Notwithstanding this similarity, courts have generally taken the position that preemptive rights do not apply in this case, unless the articles of incorporation expressly provide for such a right. ${ }^{40}$

In Borg v. International Silver Co., the Second Circuit clearly identified the rationale for excluding preemptive rights for the sale of treasury stock. ${ }^{\mathbf{1 1}}$ After stating that shareholders have a preemptive right when new shares are issued, but not in case of sale of treasury shares, the court opined that:

When a person buys into a company with an authorized capital, he accepts that proportion of the voting rights which his purchase bears to the whole. This applies certainly so far as the other shares are issued at the same time, and perhaps, also, though they are issued much later. But treasury shares have by hypothesis once been issued, and have diluted, as it were, the shareholder's voting power ab initio. He cannot properly complain that he is given no right to buy them when they are resold, because that merely restores the status he originally accepted. ${ }^{42}$

As the court explains, if shareholders had a preemptive right at the time the shares were issued, they either exercised it or decided not to. ${ }^{43}$ If they exercised their rights, they might have resold the shares to other investors, who in turn sold them to the corporation or might have sold them back to the corporation. Their preemptive right has been respected at the time of the issuing and, by selling the shares to other shareholders or to the corporation, they decided to have a lower participation in the corporation. On the other hand, if the shareholders did not exercise their preemptive rights, they accepted the dilution to their stake in the corporation at the time of the issuing of new shares.

39 An example is $\S 2.22(\mathrm{C})$ of the Texas Business Corporation Act, cited by Bittner, supra note 30 , at 911 .

${ }^{40}$ See Gevurtz, supra note 5, at 137; Enright v. Heckscher, 240 F. 863, 874 (2d

Cir. 1917); Page v. Smith, 48 Vt. 266 (1876); Crosby v. Stratton, 68 P. 130, 133 (Colo. App. 1902).

41 Borg v. Int'l. Silver Co., 11 F.2d 147 (2d Cir. 1925).

42 Id. at 151

43 See id. 
In both cases, shareholders have been given the opportunity to maintain their percentage of capital and have declined it. ${ }^{44}$

Similarly, shareholders buying shares in a corporation that already owns treasury shares accept the risk that these shares might be sold to third parties. In all these cases, shareholders cannot invoke preferential rights merely because, at a certain time, the shares have been bought back by the corporation and held as treasury stock. The only protection that shareholders have, in this case, concerns the possible damage to the value of their investment if the treasury shares are sold for less than their actual value. For this reason shareholders can expect treasury shares to be resold at their fair value, and, if not, directors might face liability. ${ }^{45}$

It is clear, therefore, that even when shareholders have a preemptive right (either a statutory one, as it was in the past, or because of a charter provision, as it might be today), that right does not extend to the sale of treasury stock. ${ }^{46}$ Obviously this conclusion also holds when shareholders do not have a preemptive right in the first place.

\section{Directors' Fiduciary Duties and Other Limitations to the Sale of New Shares}

A delicate issue that might arise is whether directors are allowed to freely sell shares only to some shareholders, therefore altering the balance of power within the corporation. In general terms we have seen that when preemptive rights do not apply, directors can sell new shares (or treasury shares) as they see fit. This freedom is, however, not unlimited. ${ }^{47}$ Consider, for example, a situation where the charter of the corporation provides for a supermajority of two-thirds of the votes to approve certain extraordinary transactions, such as a merger. One shareholder owns $60 \%$ of the outstanding shares, and another one owns $40 \%$. Can the directors sell shares only to the first shareholder, thus bringing his participation above the $66.6 \%$ threshold and giving him absolute control over those transactions? In this case, the solution should not be found in preemptive rights, but rather in directors' fiduciary duties and in the principle of equal treatment of shareholders.

As mentioned above, directors' fiduciary duties are a powerful and flexible instrument to limit directors' discretion in issuing shares. Whenever directors have a conflict of interest, the general rule is that either the transaction is approved by disinterested directors or shareholders, or that it is entirely fair to the corporation. The simplest case

\footnotetext{
${ }^{44}$ See id.

45 See id. at 152.

46 See Gevurtz, supra note 5, at 137.

${ }^{47}$ See generally id. at 273.
} 
occurs if directors issue shares to themselves or their affiliates at a bargain price. ${ }^{48}$ In this case there is a clear conflict of interest, and the transaction is not fair. To go forward, it would require the approval of disinterested parties. ${ }^{49}$ However, the situation can often be trickier.

A first problem occurs when directors issue shares to themselves at a fair price. In this case, the effect of the issuing could be a shift in control, but the rule applicable to conflicted transactions would not be very helpful because the transaction is fair to the corporation (the price is adequate) and is only unfair to diluted shareholders. ${ }^{50}$ In this scenario, some courts have taken the position that directors must demonstrate a corporate purpose for the selective sale. ${ }^{51} \mathrm{~A}$ second case deserving consideration occurs when directors offer new shares to all shareholders at a bargain price, but some shareholders do not have the financial resources or the willingness to buy additional shares. Directors might exploit the lack of financial means of one or more shareholders to dilute their participation, claiming that formally all shareholders had an equal opportunity to buy the discounted shares. ${ }^{52}$ Also, in this instance, some courts have required a business purpose for the bargain sale of the shares. ${ }^{53}$

The situation is more complicated when directors want to favor a particular shareholder with whom they have no formal affiliation, for example, because they expect that the shareholder will continue to retain them on the board of directors. To do so, they might selectively sell new shares only to this shareholder at a fair price, thus determining a shift in control or in any case diluting the voting power of other shareholders. ${ }^{54}$

In this scenario the first issue would be one of fact, demonstrating that there is a conflict of interest. The rules governing conflicted transactions, however, might not be sufficient to protect shareholders because the sale is fair to the corporation. The best solution would be to require a business purpose for the transaction, arguing that in the absence of such a purpose, shareholders should be treated equally.

\footnotetext{
48 Id. at 138.

49 Id.

50 See id. at 138-39.

51 Schwartz v. Marien, 335 N.E.2d 334 (N.Y. 1975). But see Tallant v. Executive Equities, Inc., 209 S.E.2d 159 (Ga. 1974) for an example of a case in which the court has not required a showing of business purpose. The case is illustrated by GevurTz, supra note 5, at 138.

52 See GevurTz, supra note 5, at 138.

${ }^{53}$ Id. at 138-39 (citing Katzowitz v. Sidler, 24 N.Y.2d 512, 301 N.Y.S.2d 470, 29

N.E.2d 359 (1969) as a case in point).

${ }^{54} I d$.
} 


\section{PART II: EuROPEAN LAW}

\section{The European Framework: The Second Company Law Directive}

The Second Company Law Directive, enacted in 1977 and amended several times, ${ }^{55}$ sets forth a harmonized regulation of the formation of corporations, focusing in particular on legal capital and its maintenance and alteration. Its breadth spans from the minimum amount of capital to eligible contributions and from purchasing of owned shares to distributions to shareholders. For the purposes of this essay the relevant provisions are contained in Articles 25, applicable to publicly held corporations. ${ }^{56}$ Two key principles need to be emphasized here. First, Article 25, Paragraph 1, provides that any increase in capital must be decided upon by the general shareholders' meeting. ${ }^{57}$ Second, Article 29 establishes that when the capital is increased and the new shares are paid in cash, the shares must be offered on a preemptive basis to shareholders in proportion to the capital represented by their shares. ${ }^{58}$

These two provisions establish a minimum level of harmonization that is very different from, and arguably opposite of, the American regulatory model. The European approach gives more powers to the shareholders' meeting in deciding the issuing of new shares, and mandates preemptive rights as a general rule when shares are issued for a consideration in cash.

To get a clearer sense of how the general provisions of the Second Company Law Directive have been implemented in some Member States, it is helpful to examine some specific European jurisdictions.

\section{Italian Law: Regulation of Issuing of New Shares for a Consideration}

The Italian system offers an excellent example of the way in which the regulation of issuing new shares adopted in continental Europe compares with U.S. law. In fact, as we will discuss, the Italian Civil Code (I.C.C.) follows an approach that is considered opposite to the American one, characterized by mandatory regulation that leaves little room for freedom of contract and directors' discretion. ${ }^{59}$ Under

55 Second Council Directive, Dec. 13, 1976, 1977 O.J. (L 026) 1 [hereinafter Second Council Directive] (updated by Directive 2006/68/EC of the European Parliament and of the Council of 6 September 2006, 2006 O.J. (L 264) 32 and Directive 2009/ 109/EC of the European Parliament and of the Council of 16 September 2009, 2009 O.J. (L 259)14).

${ }^{56}$ See Second Council Directive, supra note 55, art. 25.

57 Id. art. 25 para. 1.

58 Id. art. 29.

59 See generally Codice Civile [C.c.] (It.). 
Italian law, the interests of existing shareholders receive a stronger protection vis-à-vis the interest of the corporation to maintain a flexible financial structure so as not to be diluted through a capital increase.

In addition, in light of the partially harmonized regulation at the European level, the Italian system has important similarities with the systems of other major continental European jurisdictions, therefore presenting a good illustration of the European regulatory model. For these reasons, the following pages concentrate on the Italian system first and then briefly examine other European countries, such as Germany, France, Spain, and the U.K.

A first crucial difference between the Italian and American regulation and practice of issuing new shares concerns the competence to decide the increase of capital. Under Italian law, pursuant to the Second Company Law Directive, the power is primarily in the hands of the shareholders. ${ }^{60}$ The issuing of new shares for a consideration, in fact, represents an amendment to the corporate charter that can only be approved by the so-called "extraordinary" shareholders' meeting with a supermajority. ${ }^{61}$ The matter can be delegated to directors by the shareholders' meeting, pursuant to Article 2443 of the I.C.C. ${ }^{62}$ In this case, the situation is similar to the one in which a U.S. corporation has authorized but unissued shares. The delegation to directors, however, can only be given for a maximum period of five years, therefore limiting directors' freedom to issue new shares. ${ }^{63}$

Probably the most crucial difference concerns preemptive rights. In contrast to the U.S.-or, more precisely, in contrast to current U.S. rules, but similar to the traditional U.S. approach-the statutory and mandatory rule generally applicable is that, in any issuing of new shares for a consideration, all shareholders have a preemptive right to purchase the new shares proportionally to their stake in the corporation. ${ }^{64}$ Another difference with U.S. law is that, in a closelyheld corporation, the shareholders that exercise their preemptive right do not only have the right to buy the new shares pro rata, but they can also exercise an additional preemptive right on the shares that other shareholders have not bought. ${ }^{65}$ Hence, if a corporation has two shareholders and only one of them exercises her preemptive right, she has the right to also buy the percentage of shares that the other share-

\footnotetext{
${ }^{60}$ See Second Council Directive, supra note 55.

61 See Codice Crvile [C.c.] (It.).

62 Codice Civile [C.c.] art. 2443 (It.).

63 See Giuseppe A.M. Trimarchi, L'aumento del Capital sociale 337 (Iposa, 2007) (It.).

64 Codice Civile [C.c.] art. 2441, para. 1 (It.).

${ }^{65}$ Id. para. 3.
} 
holder refused, increasing her percentage of the corporation's capital. $^{66}$ Only if shareholders do not exercise this additional right of preference can directors sell the shares to third parties.

The scope of the preemptive right under Italian law is also broader with respect to the securities to which the right attaches. First, the law expressly states that the holders of bonds convertible into shares also enjoy preemptive rights and that preemptive rights can also be exercised on convertible bonds, when issued. ${ }^{67}$ The rationale for this rule is straightforward: since holders of bonds convertible into shares can potentially become shareholders, not granting preemptive rights to or on these financial instruments would allow a dilution of the position of shareholders or bondholders. It should be noted, however, that according to a recent case involving Spain, the European Court of Justice has taken the position that granting preemptive rights to holders of convertible bonds is against European law, as it reduces the number of shares available to shareholders. ${ }^{68}$

The law is not similarly clear with respect to preemptive rights when it comes to issuing different classes of shares. There is a specific rule for non-voting shares issued by listed corporations: Article 145 of the Consolidated Law on Finance. ${ }^{69}$ This rule provides that, in the absence of a different option in the corporate charter, holders of non-voting shares have a preemptive right on shares of the same class. ${ }^{70}$ If non-voting shares are not issued, holders of these shares have a preemptive right on the classes of shares that are issued. Most commentators have expressed the view that this rule is the expression of a more general principle, where preemptive rights include the right to subscribe to shares of different categories if the capital increase does not respect the proportion between the categories of shares already outstanding. ${ }^{71}$

\footnotetext{
${ }^{66}$ But see supra, Part I.

${ }^{67}$ Codice Crvile [C.c.] art. 2441, para. 1 (It.).

68 The European Court of Justice, in Case C-338/06, Commission of the European Communities v. Kingdom of Spain, held that Article 29 of the Second Directive gives to shareholders priority over all other potential purchasers of new shares and convertible bonds. It follows, according to the court, that Spanish law, which gives preemptive rights to convertible bondholders, might jeopardize shareholders' preemptive rights. In this case, the Kingdom of Spain, which has a provision similar to the Italian one cited, was considered not having fulfilled its obligations under the Second Directive.

${ }^{69}$ Legislative Decree No. 58 of 24 February 1998 Consolidated Law on Finance, art. 145 (1998) (It.).

70 See id.

71 See generally G.F. Campobasso, Diritto Commericale: Diritto delle Societa 521, n. 44 (ed. M. Campobasso) (Utet, 2012) (It.).
} 


\section{Statutory Limitations to Preemptive Rights}

Preemptive rights can be limited or excluded only in four specific and narrow circumstances, listed in Article 2441 I.C.C. ${ }^{72}$ The first circumstance applies when the resolution approving the capital increase provides that the consideration for the new shares must be a contribution in kind. ${ }^{73}$ The rationale is the same as that adopted by U.S. courts to limit contractual preemptive rights included in the corporate charter in the absence of a specific provision: the interest of the corporation to receive exactly the property it seeks to acquire trumps the interest of shareholders not to be diluted. The law suggests, however, that, even in this case, it is not sufficient that the resolution indicates a contribution in kind, but also that a specific business purpose for the contribution in kind be shown in order to not elude the right of shareholders to maintain their stake in the corporation. ${ }^{74}$

The second case in which preemptive rights do not apply is, pursuant to Article 2441, Paragraph 5 of the I.C.C., where "the interest of the corporation requires it." 75 The scope of this provision is clearly broader and more blurred, but a few examples can be derived from corporate practice. When a corporation is going public, it needs to have a minimum number of shareholders in order to be admitted to a stock exchange. The initial public offer must, therefore, be made to a broad range of investors, and preemptive rights would be an insurmountable obstacle to the creation of a widespread ownership structure. $^{76}$ In this case, the interest of the corporation to be listed arguably requires that preemptive rights be limited. This may occur, for example, when a corporation wants to attract a new shareholder in order to become part of a corporate group, or to exploit the business relationships and expertise of the new shareholder.

Similar to the U.S. model, a third possible exclusion of preemptive rights can be based on an intention to compensate employees with shares of the corporation. Pursuant to Article 2441, Paragraph 8 of the I.C.C., when new shares are offered to employees, a maximum of one-fourth of the new shares can be sold without granting existing shareholders a preemptive right. ${ }^{77}$ It should be noted, however, that the limitation on preemptive rights can only affect $25 \%$ of the newly issued shares in order to curb the possible dilution of existing shareholders. ${ }^{78}$

\footnotetext{
72 Codice Civile [C.c.] art. 2441 (It.).

${ }^{73}$ Codice Civile [C.c.] art. 2441, para. 4 (It.).

74 See Trimarchi supra note 63 , at 323 n. 259.

${ }^{75}$ Codice Civile [C.c.] art. 2441, para. 5. (It.)

76 See generally GevurTz, supra note 5.

77 Codice Civile [C.c.] art. 2441, para. 8 (It.).

${ }^{78}$ Id.
} 
The fourth and last situation in which preemptive rights can be limited applies only to listed corporations. This is a relatively recent innovation introduced in 2003 and inspired by German law. ${ }^{79}$ Article 2441, Paragraph 4 of the I.C.C. provides that the charter of a listed corporation can opt for the possibility of increasing the amount of outstanding shares up to $10 \%$ of their number without granting preemptive rights. ${ }^{80}$ The rationale of this rule is to give more flexibility to listed corporations in designing their financial structure by allowing the issuing and selling of new shares without the time-consuming offer to existing shareholders required by preemptive rights. In a listed corporation, when shares are traded on a liquid regulated market, the risk of shareholders' dilution is more limited: existing shareholders that want to maintain their position in the corporation can, in fact, easily buy additional shares on the market.

As mentioned above, these four exceptions to mandatory preemptive rights are the only ones allowed: contribution in kind, interest of the corporation, shares offered to employees, and $10 \%$ of the outstanding shares in listed corporations. ${ }^{81}$ Only in these cases can the stake of a shareholder in the corporation be diluted if the shareholders' meeting so decides. The law, however, provides for specific rules concerning the issuing price of the new shares in case of limitation or exclusion of preemptive rights, in order to avoid an economic damage to investors. The selling price of the shares cannot, in these cases, be lower than a fair price determined through specific procedures.

More precisely, in the first three cases listed above, the directors must present the shareholders with a proposal indicating the issuing price calculated on the basis of the actual value of the corporation, taking into account, in the case of listed shares, their market price in the last six months. ${ }^{82}$ The proposal also must be shared with the auditors of the corporation, who must issue an opinion on the fairness of the issuing price. ${ }^{83}$ In the last case where preemptive rights can be limited, concerning $10 \%$ of the outstanding shares in listed corporations, the issuing price must be equal to the "market value" of the shares, and the auditing firm must confirm this equivalence. ${ }^{84}$

In the four cases when preemptive rights can be excluded, directors are not free to issue the new shares to one or some of the ex-

\footnotetext{
79 See Gaia Balp \& Marco Ventoruzzo, Esclusione del diritto d'opzione nelle società con azioni quotate nei limiti del dieci per cento del capitale e determinazione del prezzo di emissione, 49 Rivista delle Società 795 (2004) (It.).

80 Codice Civile [C.c.] art. 2441, para. 4 (It.).

81 See generally id. art. 2441.

82 See id. art. 2441, para. 6.

83 See id.

84 See id. para. 4.
} 
isting shareholders, thus increasing their participation in the corporation. On the one hand, the statutory language relating to the circumstances under which preemptive rights can be excluded limits the ability of directors to sell the shares only to some shareholders. Consider the case of contributions in kind. Only if a business purpose justifies the acquisition of property owned by a specific shareholder can the new shares be sold only to this investor. The same is true in the few cases in which the interest of the corporation requires the exclusion of preemptive rights, or when preemptive rights are excluded for the benefit of employees.

In addition, general corporate law principles require equal treatment of all shareholders. ${ }^{85}$ Pursuant to this principle, it is difficult to justify the exclusion of preemptive rights and the simultaneous sale of shares to a selected number of shareholders, leaving the other ones out in the cold.

Also under Italian law, as in the U.S., there are no preemptive rights in the case of merger. Unlike the U.S., however, Italian law, pursuant to European law, does not allow cash-out mergers. As a consequence, generally all shareholders of the corporations involved receive a proportionally identical percentage of shares in the corporation resulting from the merger, calculated on the basis of the exchange ratio. $^{86}$

Finally, in Italy there are no specific rules concerning the resale by the corporation of treasury shares, which in theory, could be sold to only some shareholders. This practice would however be subject to scrutiny based on the above-mentioned principle of equal treatment of shareholders.

In this section we have considered how shareholders are protected against possible dilutions caused by the issuing of new shares under Italian law. To sum up, we have seen that Italian law, in comparison to U.S. law, provides for more rigid rules against dilutions. First, the competence to issue new shares for a consideration is more firmly in the hands of the shareholders. Second, all shareholders have a mandatory preemptive right established in the corporate statute-a

85 A general principle of equal treatment of shareholders under European company law has also been inferred by the European Court of Justice in the "Audiolux" case. See Federico M. Mucciarelli, Equal Treatment of Shareholders and European Union Law, 7 Eur. Co. \& FIN. L. Rev. 158 (2010). For a study of the principal of equal treatment of shareholders in Italy, see generally Carlo Angelici, Parità di trattamento degli azionisti, Rivista di Diritto Commerciale 1 (1987) (It.). In specifically listed corporations, see Marco Ventoruzzo, Article 92. Parità di trattamento, in LA Disciplina DELLE SOCIETÀ qUOTATE (Vol. I, Giuffrè, 1999) (Piergaetano Marchetti \&Luigi A. Bianchi eds.).

${ }_{86}$ See Marco Ventoruzzo, Freeze-outs: Transcontinental Analysis and Reform Proposals, 50 VA. J. INT'L L. 841,887 (2010). 
right that can be waived only in narrow circumstances. If the rights are waived, mandatory rules ensure that the issuing price is fair and specifically, not lower than the actual value of the shares.

\section{Italian Law: Directors' Fiduciary Duties}

Directors can be liable to the corporation or to a single shareholder for a violation of their duty of care and loyalty, which include the duty to act lawfully ${ }^{87} \mathrm{~A}$ violation of the mandatory rules concerning the procedures required for issuing new shares can therefore result in liability to the corporation and to single shareholders. Liability to the corporation occurs when the corporation suffers the damage, and shareholders can also act derivatively on behalf of the corporation. When the damage only affects shareholders and does not implicate damage to corporate assets, shareholders also have a direct cause of action against directors.

Not respecting the rules concerning preemptive rights can be a source of liability in at least two circumstances. For one, illegally excluding preemptive rights can damage shareholders by diluting their investment. Additionally, setting an issuing price below the fair value in the cases in which the preemptive right is excluded can damage both the corporation (which receives less than the actual value of the shares), and the shareholders (whose participation loses value).

This type of lawsuit is fairly rare, for at least two reasons. First, the procedure to issue new shares is tightly regulated, as are the cases in which the preemptive right can be limited. This regulatory approach leaves little room for directors' discretion. To incur liability, directors would have to blatantly disregard the law by, for example, denying preemptive rights when shareholders are entitled to them. In other words, director liability arises more easily when directors have more freedom to act, and a breach of the duty of care or of loyalty is possible; there is a direct relationship between discretion and accountability. When mandatory provisions govern an area of the law, violations of fiduciary duties tend to be more rare.

There is a second and more general reason why directors' fiduciary duties do not play the same role in Italy that they play in the U.S. The Italian system relies less on private litigation as an ex post mechanism to govern corporations, for a number of reasons, including procedural ones. The absence of a U.S. style class action and of discovery, the existence of a "loser pays" rule, the unavailability of contingency fees to retain lawyers, and the extremely long duration of civil

${ }^{87}$ For an overview of the concept of directors' fiduciary duties in Europe, see generally Holger Fleischer, Legal Transplants in European Company Law-The Case of Fiduciary Duties, 2 Eur. Company AND Fin. L. Rev. 378 (2005). 
litigation contribute to reduce the attractiveness of litigation as a means to protect preemptive rights of disgruntled shareholders. ${ }^{88}$

\section{Germany}

Pursuant to the Second Company Law Directive under German law, an increase of capital for consideration must be decided by the shareholders' meeting and represents an amendment to the corporation's charter. There is a double majority requirement, because the resolution must be approved by a simple majority of the votes, representing at least three-quarters of the voting capital. ${ }^{89}$ The corporate charter or bylaws can increase these percentages to further protect shareholders. ${ }^{90}$ In addition, if the corporation has issued different classes of shares, any capital increase affecting the rights of a class of shares must also be approved by a class vote. ${ }^{91}$

Shareholders can delegate the power to increase the capital to directors generally, or for specific purposes. ${ }^{92}$ In the former case, the delegation can be given only for a maximum period of five years, similar to Italian law, and the capital increase cannot exceed 50\% of the outstanding shares. ${ }^{93}$ Rules concerning preemptive rights in Germany (Bezugsrecht) are particularly rigid. Generally, shareholders always have a mandatory preemptive right, both when the new shares are issued for cash and when issued for assets in kind. ${ }^{94}$ Shareholders may waive their preemptive rights, but only through a resolution, voted on by three-quarters of the capital represented at the meeting and based on a report prepared by the executive board (Vorstand), stating the reasons why the exclusion of preemptive rights is in the company's best interest. ${ }^{95}$ Courts also require managers to show that the corporation has a valid business purpose to limit preemptive

${ }^{88}$ For an excellent and recent analysis of these procedural elements, and an explanation of why they can limit the use of corporate litigation in European countries, including Italy, see Martin Gelter, Why Do Shareholders Derivative Suits Remain Rare in Continental Europe?, 37 BRoOK. J. INT'L L. 843 (2012).

89 Aktiengesetz [AKTG] [Stock Corporation Act], Sep. 6, 1965, BGBL. I at 1089, $\$ 182$ (1) (Ger.), translated in Stock Corporation Act, Norton Rose (1 Dec. 2011) [hereinafter Stock Corporation Act]; see also CAHN \& Donald supra note 3, at 197; see generally Gerhard Wirth et al., Corporate Law in Germany 179 (C.H. Beck, 2nd ed., 2010).

90 See Stock Corporation Act, supra note 89, at 1089, § 182 (1) (Ger.), translated in Stock Corporation Act, Norton Rose (1 Dec. 2011).

91 Stock Corporation Act, supra note 89, § 182 (2).

92 Id. $\$ \$ 202 ; 186$.

93 CAHN \& Donald, supra note 3 , at 198.

94 See Stock Corporation Act, supra note 89, at 1089, § 186(1) (Ger.), translated in Stock Corporation Act, Norton Rose (1 Dec. 2011).

${ }^{95}$ Id. § 186(3)-(4). 
rights. ${ }^{96}$ When preemptive rights are waived, the issuing price of the new shares must be appropriate, and shareholders have an explicit cause of action to challenge the price in court. ${ }^{97}$

In the 1990s, the German corporate statute was amended to allow the exclusion of preemptive rights in listed corporations if the new shares are paid in cash. ${ }^{98}$ In this case, the capital increase cannot exceed $10 \%$ of the outstanding shares, and the issuing price cannot be lower than the market price. ${ }^{99}$ This ground for limiting preemptive rights is, as previously discussed, similar to one of the four grounds for exclusion under Italian law. ${ }^{100}$

\section{France}

Under French law, issuing new shares for a consideration is subject to specific formalities designed to protect shareholders against the risk of dilution. The power to decide the capital increase is, as in other European jurisdictions, in the hands of the so-called extraordinary shareholders' meeting and is subject to supermajority requirements (two thirds of the votes cast). ${ }^{101}$ The shareholders can, however, delegate the power to the directors pursuant to Article L. 225-129 of the Commercial Code and, in listed companies, the delegation can also be given to the CEO. ${ }^{102}$

When France introduced mandatory preemptive rights in $1935,{ }^{103}$ the legislature allowed preemptive rights to be waived by the

${ }^{96}$ See Bundesgerichtshof [BGH] [Federal Court of Justice] Mar. 13, 1978, II ZR 142/76 EnTsCheidungen DES BundesGerichtshofes IN ZivilsaCHEN [BGHZ] 71 (40) (Ger.); Bundesgerichtshof [BGH] [Federal Court of Justice] Apr. 19, 1982, II ZR 55/81 ENTSCHEIDUNGEN DES BUNDESGERICHTSHOFES IN ZIVILSACHEN [BGHZ] 83 (319) (Ger.); CAHN \& Donald, supra note 3, at 201-02; see also Heribert Hirte, Bezugsrechtsausschluss und Konzernilldung 58 ff. (Heyman, 1986).

${ }_{97}$ Stock Corporation Act, supra note 89, at 1089, § 255(2)-(3) (Ger.), translated in Stock Corporation Act, Norton Rose (1 Dec. 2011). Veil, in Schmidt and Lutter (2008: § $182 \mathrm{mn} .23)$.

${ }^{98}$ Id. $\S 186(3)$.

${ }^{99}$ Id. § 255(2)-(3).

${ }^{100}$ WIRTH ET AL., supra note 89, at 179.

101 Maurice Cozian ET. AL, Droit des Societes 457 (LexisNexis, 25th ed., 2012) (Fr.).

102 Code de Commerce [C. COM.] art. L.225-129-1 (Fr.); see also id. n. 61.

103 See Frédéric Serpoul, Beyond Legal Origins: Shareholder Protection and Stock Market Development in France (1852-2007) 19 (London School of Economics and Political Science, Working Paper, June 15, 2013) ("Shareholder rights improved significantly in the mid-1930's through changes intiatied by the Laval government [. . .]. In particular, as a result of the 1935 laws which granted preemptive rights to shareholders in order to prevent majority shareholders abuses (dilution), LLSV shareholder right index rose to $2 . "$ ). 
shareholders' meeting, not dissimilarly from what was happening in some U.S. States. ${ }^{104}$ France still provides for mandatory preemptive rights in Article L. 225-132 of the Commercial Code. ${ }^{105}$ The extraordinary shareholders' meeting can, however, waive preemptive rights. In this case, the resolution must indicate the persons that will subscribe to the shares, or the criteria that the subscribers must meet. ${ }^{106}$ In listed corporations, the indication of the beneficiary of the shares is not necessary. ${ }^{107}$ Also in listed corporations, the Commercial Code provides that when preemptive rights are waived the shareholders' meeting can give existing shareholders a term during which they can subscribe the shares before third parties. ${ }^{108}$ Preemptive rights also do not apply when the extraordinary shareholders' meeting approves an increase of capital paid with consideration in kind. ${ }^{109}$ It can be observed, therefore, that France also views preemptive rights as the default rule, and that preemptive rights can only be waived with the consent of the controlling shareholders.

Specific rules apply to the determination of the issuing price when preemptive rights are waived. The general rule, applicable when the shareholders' decision indicates the beneficiaries acquiring the new shares, is that the price can be determined by the shareholders' meeting. ${ }^{110}$ In listed corporations, when the beneficiaries of the new shares are not indicated, the price must be in line with the trading price in order to avoid a prejudice to the value of the existing shareholders' shares. ${ }^{111}$

\section{Spain}

Under the Spanish Ley de Sociedades de Capital, the competence to increase the capital is primarily in the hands of the shareholders' meeting. The shareholders can, however, delegate this power to the board of directors for a period of five years, although in this case the amount of the increase is limited to fifty percent of the outstanding capital. ${ }^{112}$

\footnotetext{
104 Katharina Pistor et al., The Evolution of Corporate Law: A Cross-Country Comparison, 23 U. PA. J. INT'L ECoN. L. 791, 825 (2002).

${ }^{105}$ Sofie Cools, The Real Difference in Corporate Law Between the United States and Continental Europe: Distribution of Powers, 30 DEL. J. CoRP. L. 697, 729 (2005).

106 Code de Commerce [C. COM.] art. L.225-138 (Fr.).

107 Maurice Cozian ET. AL., supra note 101, at 459.

108 Code de Commerce [C. COM.] art. L.225-135-5 (Fr.); Maurice Cozian et al., supra note 101, at 459 .

109 Maurice Cozian ET AL., supra note 101, at 462.

110 Code de Commerce [C. com.] art. L.225-138 (Fr.).

111 See Code de Commerce [C. COM.] art. L.225-136 (Fr.).

112 Corporations Act art. 297 (B.O.E. 2010, 161) (Spain).
} 
As a general rule, when new shares are issued, existing shareholders have a preemptive right (derecho de preferentia). After a 2008 decision of the European Court of Justice, bondholders no longer have preemptive rights when new shares are issued. ${ }^{113}$ This right can be totally or partially waived by the shareholders when the interest of the corporation requires it. In this case, the directors must prepare a report to the shareholders indicating the value of the shares, the reasons for the exclusion of the preemptive right, and the investors that will subscribe the new shares. An independent appraiser appointed by the Office of the Corporate Register must calculate the value of the shares and of the preemptive rights that are excluded, and must assess the soundness of the value of the shares included in the directors' report. The issuing price cannot be lower than the fair value of the shares. ${ }^{114}$

\section{United Kingdom}

In the U.K., pursuant to European law, directors may issue new shares only if authorized by the corporate charter or by the shareholders; the authorization must specify the maximum number of shares that can be issued and can only be given for a period of five years. ${ }^{115}$ U.K. law gives, however, more extensive powers to directors in the case of a close company with only one class of shares. In this case, the directors are free to issue new shares unless there is an explicit prohibition in the articles of incorporation. ${ }^{116}$

The English corporate law statute introduced preemptive rights (also called "rights issue") to comply with European Union law. 117 The relevant provisions can be found in the Companies Act, Part 17 , Chapter $3, \S 560 .{ }^{118}$ It is interesting to point out that, different from the U.S. and even other European systems, preemptive rights also apply in the case of a sale of treasury shares held by the company. ${ }^{119}$

U.K. law distinguishes between exceptions, exclusions, and disapplication of preemptive rights. Exceptions include the case in which shares are paid other than in $\operatorname{cash}^{120}$ and when the shares are des-

${ }^{113}$ The European Court of Justice declared this provision in violation of the Second Directive because granting preemptive rights to convertible bondholders limits the number of shares available for shareholders, contrary to the provision of the Directive; see Case C-338/06 supra note 68.

114 Manuel Broseta Pont \& Fernando Martinez Sanz, Manual de Derecho MerCantil 460 (19th ed., 2012) (Sp.).

115 Companies Act, 2006, c. 2, \$551 (U.K.).

116 Brenda Hannigan, Company Law 460 (3d ed. 2012).

117 Pistor et al., supra note 104 , at 825 .

118 Companies Act, 2006, c. 3, § 560 (U.K.).

119 Id. $\$ 573$.

${ }^{120}$ Id. $\$ 565$. 
tined to an employees' share scheme. ${ }^{121}$ The articles of incorporation of a close corporation can exclude preemptive rights pursuant to $\S 567$ of the Companies Act, which provides an opt-out mechanism. In addition, the directors of a private company that has only one class of shares outstanding can be given, by the articles of incorporation or by the shareholders, the power not to apply preemptive rights. ${ }^{122}$

\section{PART III: ConClusions}

This overview of the rules governing issuing of new shares in the U.S. and in some European jurisdictions has shown a few basic, but important, comparative differences. In the U.S., within the limit of authorized shares, directors have significant freedom to increase capital. This freedom is enhanced by the practice of authorizing a number of shares significantly higher than the number of outstanding shares, but is partially curbed by rules requiring shareholders' approval when the issuing of new shares might determine a shift in control. In terms of competence, the differences with European jurisdictions are not particularly profound.

It is true that, in Europe, the competence to issue new shares is generally attributed to the shareholders' meeting, while in the U.S., the powers of directors are original and undelegated. ${ }^{123}$ However, it is also true that in Europe shareholders can delegate their power to issue new shares to directors, even if there are some limitations to this power, such as the fact that the delegation is only valid for five years. Through a delegation, therefore, European directors can also be entrusted with a meaningful degree of freedom in issuing new shares.

The real and profound difference concerns preemptive rights. Generally speaking, most American statutes, including the M.B.C.A. and Delaware law, do not provide for preemptive rights. These rights are only available through a specific option in the articles of incorporation, and virtually no listed corporations make such an option. Shareholders are protected against the risk of unfair dilution primarily through directors' fiduciary duties. In Europe, as the Italian example clearly shows, shareholders' preemptive rights are mandatory and can only be waived in limited circumstances when the interest of the corporation requires it. When shareholders waive their preemptive rights, the issuing price generally cannot be lower than the fair market value of the shares. Comparatively, directors' fiduciary duties play a more limited role in protecting shareholders.

What does this difference tells us about the forces that shape corporate law on the two sides of the Atlantic? How does this compari-

121 See id. $\$ 566$.

122 Id. $\$ 569$.

${ }^{123}$ See Manson v. Curtis, 119 N.E. 559, 562 (N.Y. 1918). 
son reflect on the structure of corporate law? It is tempting to characterize the European approach, and the Italian approach in particular, as more regressive when compared to its U.S. counterpart. After all, with some differences, the U.S. adopted mandatory preemptive rights in the past but abandoned them in favor of a more flexible rule that allows corporations, and their directors, to follow a more expeditious and efficient procedure to sell new shares. To simply dismiss the European approach as a relic of the past would not, however, be a satisfactory conclusion.

A second and more compelling explanation of the diverging approaches might be based on the degree of separation between ownership and control. In the U.S., at an earlier stage, the separation between ownership and control became more profound, resulting in managers and directors becoming key players in shaping corporate laws. Directors and managers, selecting the state of incorporation, can put pressure on the legislatures to adopt the rules that they favor. This was probably one of the driving forces that induced state legislatures to abolish mandatory preemptive rights. ${ }^{124}$

In Europe the situation is radically different. Notwithstanding the recent developments of the jurisprudence of the European Court of Justice, ${ }^{125}$ in Europe there is not, and probably never will be, a market for corporate charters as developed as the American one. In addition, prevailing ownership structures are profoundly different from the U.S. In most continental systems, controlling shareholders are still very influential both within the corporation and vis-à-vis policy makers. In the U.K., while ownership structures of public corporations are more

\footnotetext{
124 John Armour and David A. Skeel, Jr., Who Writes the Rules for Hostile Takeovers, and Why? - The Peculiar Divergence of U.S. and U.K. Takeover Regulation, 95 GEo. L. J. 1727 (2007) advances a fascinating public choice explanation for the differences in takeover regulation in the U.K. and in the U.S. The former system seems to favor managers and directors against hostile acquisitions, while the latter favors institutional investors through the use of the mandatory tender offer rule and the passivity rule. In short, they advocate that this difference can be explained in the light of the influence of institutional investors on the development of U.K. rules, and of directors and managers in the U.S. A similar argument could be used for the regulation of preemptive rights: in the U.S., stronger managers and directors managed to shift the regulatory approach to greater flexibility in the issuance of new shares, while in Europe institutional investors and controlling shareholders pushed for a stronger protection of their investment through mandatory preemptive rights.

${ }^{125}$ See Marco Ventoruzzo, "Cost-based" and "Rules-based" Regulatory Competition: Markets for Corporate Charters in the U.S. and in the E.U., 3 N.Y.U. J.L. \& Bus. 91, 133-35 (2006); Veronika Korom \& Peter Metzinger, Freedom of Establishment for Companies: The European Court of Justice Confirms and Refines its Daily Mail Decision in the Cartesio Case C-210/06, 6 Eur. Company and Fin. L. Rev. 125 (2009).
} 
widespread than in continental Europe, institutional investors are particularly strong. As a result, it is more difficult for directors and managers to obtain a legislative departure from preemptive rights that protect the interests of existing shareholders. The Second Directive and the regulatory approaches of the Member States reflect this situation: mandatory preemptive rights are still considered a cornerstone of corporate law, and shareholders play a more crucial role in controlling the issuing of new shares.

The explanation based on ownership structure is not completely satisfactory. It might be argued that in listed or publicly held corporations, where the separation between ownership and control is more profound in the U.S., directors and managers influenced the development of corporate law toward the abolition of mandatory preemptive rights. But the shift in the U.S. also affected close corporations, in which the degree of separation between ownership and control is lower. Also in these corporations, as we have seen, directors have broader, non-delegable powers to issue new shares, and preemptive rights are generally not available unless the governing documents of the corporation provide for them. The prevailing ownership structures of the firms do not, therefore, seem to fully capture the reasons that led the U.S. to substantially abolish mandatory preemptive rights in all types of corporations.

An alternative theory might be that the diverging development of U.S. and European laws on preemptive rights reflects a more general "cultural" difference concerning the function of corporate law. In the U.S., shareholders are considered investors able to contract the basic rules of the corporate contract among themselves and with other corporate actors. From this point of view, it makes sense to provide for preemptive rights only on an optional basis. Freedom of contract is considered a sufficient protection for shareholders, as they are able to maximize efficiency. If shareholders want preemptive rights, they will include them in the charter of the corporation.

In Europe, by contrast, there is not a similar trust in the virtues of contractual liberty: property rights of shareholders are more strongly protected through mandatory rules, at the expense of a more flexible financial structure that would allow directors and managers to obtain fresh financial resources from new investors more quickly. The greater discretion of directors in the U.S. is balanced in this area, by the policing role of litigation for breaches of fiduciary duties, while litigation in Europe plays a lesser role. 